\title{
STRATEGI HUBUNGAN MASYARAKAT DALAM MENINGKATKAN CITRA ORGANISASI NIRLABA WORLD WIDE FUND FOR NATURE - INDONESIA
}

\section{Public Relations Strategies to Increase Image Non-profit World Wide Fund for Nature - Indonesia}

\author{
Adella Adiningtyas ${ }^{1)}$, Aida Vitayala S Hubeis ${ }^{1)}$ dan Dwi Retno Hapsari ${ }^{1)}$ \\ ${ }^{1)}$ Departemen Sains Komunikasi dan Pengembangan Masyarakat, Fakultas Ekologi Manusia, Institut \\ Pertanian Bogor, Darmaga Bogor 16680, Indonesia \\ Email: adelladiningtyas@gmail.com; aidahubeis@apps.ipb.ac.id; retnokpm@apps.ipb.ac.id
}

\begin{abstract}
Non-profit organizations engaged in environmental issues has been increasingly recognized by many people. The success of non-profit organizations that pursued by increasing the positive image obtained from media relations. This study aimed to analyze the strategy of Public Relations (PR) WWF-Indonesia in improving the image of the organization. This study was conducted with a quantitative approach and qualitative approach. The method used is survay on two student organizations Bogor Agricultural University who worked with WWFIndonesia, they are from Fisheries Diving Club (FDC) and the Association of Student Interest in Sciences of Communication and Community Development (HIMASIERA). Data analysis included Spearman Rank test and Chi Square used to look at the relationship between PR strategy with the image of a non-profit organization. The results of the study, namely: 1) there is a relationship between individual characteristics with the image of a company that is formed; 2) there is a relationship between the public relation activities undertaken by the company's image.
\end{abstract}

Keywords: environmental issue, media relation, student organizations

\begin{abstract}
ABSTRAK
Organisasi nirlaba yang bergerak di isu-isu lingkungan telah semakin diakui oleh banyak orang. Keberhasilan organisasi nirlaba yang dikejar dengan meningkatkan citra positif yang diperoleh dari hubungan media. Penelitian ini bertujuan untuk menganalisis strategi hubungan masyarakat WWF-Indonesia dalam meningkatkan citra organisasi. Penelitian ini dilakukan dengan pendekatan kuantitatif dan pendekatan kualitatif. Metode yang digunakan adalah survai pada dua organisasi mahasiswa Institut Pertanian Bogor yang bekerja dengan WWFIndonesia yang berasal dari Fisheries Diving Club (FDC) dan Asosiasi Mahasiswa Peminat Ilmu Komunikasi dan Pengembangan Masyarakat (HIMASIERA). Analisis data termasuk uji Rank Spearman dan Chi Square, digunakan untuk melihat hubungan antara strategi PR dengan citra sebuah organisasi nirlaba. Hasil studi, yaitu: 1) terdapat hubungan antara karakteristik individu dengan citra perusahaan yang terbentuk; 2) ada hubungan antara kegiatan hubungan masyarakat yang dilakukan oleh citra perusahaan.
\end{abstract}

Kata kunci: isu lingkungan, hubungan media, organisasi mahasiswa 


\section{PENDAHULUAN}

Kondisi lingkungan hidup yang sudah semakin rusak dan tercemar menjadi perhatian banyak kalangan. Kerusakan dan pencemaran lingkungan yang semakin menghawatirkan kehidupan manusia disebabkan oleh pola kebijakan pembangunan yang hanya bertujuan untuk memenuhi tuntutan organisasi jangka pendek tanpa mempertimbangkan dampak penting terhadap lingkungan hidup jangka panjang (Sutrisno 2013). Manusia berkewajiban untuk bertanggung jawab mengembalikan fungsi lingkungan yang sudah rusak melalui kegiatan yang diadakan oleh organisasi nirlaba yang bergerak pada isu lingkungan hidup.

Undang-Undang No. 30 Tahun 2008 Pasal 7 mengenai Pedoman Umum Tata Kelola Kehumasan di Lingkungan Instansi Pemerintah mengamanatkan bahwa setiap badan publik wajib membangun dan mengembangkan sistem informasi dan dokumentasi untuk mengelola informasi publik secara baik dan efisien. Saat ini, semakin banyak organisasi nirlaba yang fokus pada permasalahan lingkungan dengan melakukan promosi serta adanya aktivitas Hubungan Masyarakat (Humas).

World Wide Fund for Nature atau WWF-Indonesia merupakan sebuah organisasi nirlaba Internasional yang memiliki tujuan yang sesuai dengan UU Pengelolaan Lingkungan Hidup yang mendasari kebijaksanaan lingkungan di Indonesia. Kegiatan yang dilakukan menyangkut promosi dan publikasi pelestarian lingkungan dengan menawarkan solusi yang akan membantu masyarakat dalam menjaga lingkungan sekitar. WWF-Indonesia merupakan salah satu organisasi konservasi independen terbesar di Indonesia sejak tahun $1962^{1}$. Humas merupakan alat yang digunakan untuk membangun hubungan baik dengan publik internal dan eksternal organisasi nirlaba hingga tercapainya tujuan dari kegiatan konservasi lingkungan yang dilakukan WWF-Indonesia.

Aktivitas Humas organisasi nirlaba diperlukan agar terbangunnya citra positif di mata publik. Pelaksanaan startegi yang tepat melalui Humas dengan hubungan media dapat meningkatkan publisitas perusahaan di hadapan stakeholders dengan menanamkan kepercayaan serta

\footnotetext{
${ }^{1}$ Data ini diperoleh dari website WWF-Indonesia (http://www.wwf.or.id/tentang_wwf/visi_dan_misi2/)
}

membangun reputasi baik untuk memperoleh citra positif (Khadijah 2011). Strategi yang dilakukan setiap organisasi berbeda untuk mencapai tujuan akhir. Peranan Humas dalam membangun citra positif akan terlaksana dengan adanya strategi yang terencana dan matang, karena citra organisasi di mata publik dapat dilihat dari pendapat publik saat mempersiapkan realitas yang terjadi (Susanti 2013).

Keberhasilan aktivitas humas dalam menciptakan citra positif dapat diperoleh dari hubungan baik yang sudah terjalin dengan media. Penyebaran informasi melalui media memudahkan organisasi untuk mengenalkan produk jasa atau barang. Menurut Susanto (1992) dalam Sulistyasningtyas (2004), media massa saat ini merupakan komoditas modern yang memiliki kelebihan dengan menawarkan kemungkinan untuk membentuk komunitas dengan kekuasaan sehingga terjadi suatu pola hubungan yang tali menali antara organisasi dan media. Peran media menjadi vital bagi kelancaran kegiatan konservasi lingkungan WWFIndonesia dalam publisitas dan pencitraan di mata publik. Media dapat mengambil keuntungan saat melakukan publikasi organisasi nirlaba.

Sepak terjang LSM pada bentuk organisasi lingkungan dalam menyalurkan aspirasi masyarakat terhadap isu pelestarian lingkungan hidup menuai berbagai kritikan tajam dari artikel yang dimuat di berbagai media (Paskual dan Ansar 2012). Hal ini didasarkan pada tidak terjalinnya hubungan baik di antara LSM dan media massa. Selain itu, penyajian informasi aktivitas organisasi pada masyarakat yang kurang dapat menjadi pemicu kritik publik yang tidak paham akan kejadian yang sebenarnya. Secara tidak langsung, pandangan publik yang awalnya baik menjadi tidak baik pada organisasi yang diberitakan negatif di media massa. Hal ini mengharuskan adanya hubungan baik di antara organisasi nirlaba pada aktivitas Humas perlu dibangun dengan media.

Berdasarkan latar belakang di atas, masalah penelitian adalah sebagai berikut:

1. Bagaimana upaya organisasi menyusun strategi Humas WWF-Indonesia dalam meningkatkan citra organisasi?

2. Bagaimana aktivitas Humas yang dilakukan organisasi terhadap tingkat citra perusahaan yang terbentuk?

3. Bagaimana hubungan karakteristik pengguna media massa dan aktivitas Humas yang 
dilakukan terhadap tingkat citra perusahaan?

4. Bagaimana usulan strategi yang diterapkan oleh Humas WWF-Indonesia dalam meningkatkan citra organisasi?

Berdasarkan masalah penelitian di atas, tujuan penelitian adalah sebagai berikut:

1. Menganalisis strategi yang dilakukan Humas WWF-Indonesia dalam meningkatkan citra organisasi.

2. Menganalisis citra oganisasi yang terbentuk melalui kegiatan WWF-Indonesia terhadap aktivitas Humas yang dilakukan.

3. Menganalisis citra organisasi yang terbentuk terhadap kegiatan WWF-Indonesia berdasarkan karakteristik pengguna media dan aktivitas Humas.

4. Merumuskan usulan strategi bagi Humas WWF-Indonesia dalam meningkatkan citra organisasi.

\section{PENDEKATAN TEORITIS}

\section{Hubungan Masyarakat}

Humas merupakan salah satu cabang ilmu komunikasi yang berorientasi untuk mewujudkan hubungan baik dan harmonis antara publik internal maupun eksternal menjadi sasaran utama dalam mewujudkan jalinan hubungan (Nur 2013). Menurut Jefkins (1992), Humas adalah semua bentuk komunikasi yang terencana, baik itu ke dalam maupun ke luar, antara suatu organisasi dengan semua khalayaknya dalam rangka mencapai tujuantujuan spesifik yang berlandaskan pada saling pengertian. berbagai pihak yang terlibat dalam proses produksi pesan-pesan komunikasi massa.

\section{Citra}

Citra merujuk pada pendapat Jefkins (1992), terdapat lima jenis citra dalam organisasi atau perusahaan, yaitu citra bayangan, citra yang berlaku, citra yang diharapkan, citra perusahaan dan citra majemuk, sedangkan menurut Buchari (1992) dalam Novianti (2010), citra merupakan kesan, opini, pandangan, impresi, perasaan atau persepsi yang ada pada publik mengenai perusahaan, suatu objek lembaga atau lembaga. Humas menyandang reputasi yang baik sekaligus yang buruk pada suatu organisasi. Hal ini diciptakan pribadi Humas dari sumber citra positif atau negatif yang bisa dilihat dari tingkat citra perusahaan yang diukur.

\section{Strategi Hubungan Masyarakat}

Strategi Humas dibutuhkan organisasi untuk bisa mempengaruhi publik. Menurut Cutlip et al. (2005) dalam Morissan (2008), organisasi atau perusahaan dalam bentuknya yang paling maju saat ini sudah menggunakan Humas sebagai salah satu cara untuk memecahkan masalah yang dihadapi.

Ruslan (2001) menjelaskan berbagai macam aspek pendekatan atau strategi Humas suatu organisasi, yaitu:

1. Strategi Operasional, dilakukan melalui pelaksanaan program Humas yang dilaksanakan dengan pendekatan kemasyarakatan melalui mekanisme sosial kultural dan nilai-nilai yang berlaku di masyarakat. Humas organisasi harus memiliki kemampuan atau kemauan untuk mendengar (listening) bukan sekedar hear mengenai aspirasi yang diberikan masyarakat.

2. Pendekatan Persuasif dan Edukatif, dilakukan terkait fungsi Humas, yakni menciptakan komunikasi dua arah timbal balik dengan menyebarkan informasi dari organisasi kepada pihak publiknya. Beragam sifat informasi yang diberikan, yaitu mendidik, memberikan penerangan maupun dengan melakukan pendekatan persuasif,menghargai, pemahaman, toleransi, dan sebagainya.

3. Pendekatan Tanggung Jawab Sosial Humas, dilakukan Humas untuk menumbuhkan sikap bahwa sasaran dan tujuan yang hendak dicapai bukan hanya untuk memperoleh keuntungan sepihak, tetapi memperoleh keuntungan bersama dengan motivasi tanggung jawab sosialnya.

4. Pendekatan Kerjasama, Humas berupaya membina hubungan yang harmonis antara organisasi dengan stakeholders untuk meningkatkan kerjasama. Kewajiban yang dimiliki dalam melakukan pendekatan kerjasama ialah dengan memasyarakatkan misi instansi yang diwakilinya agar dapat diterima masyarakat.

5. Pendekatan Koordinatif dan Integratif, dijelaskan dengan fungsi Humas dalam arti sempit yang hanya mewakili suatu organisasi, tetapi peranan lebih luas berpartisipasi dalam menunjang program pembangunan nasional dan mewujudkan ketahanan nasional di bidang politik, ekonomi, sosial budaya (Poleksosbud), dan Hankamnas. 


\section{Organisasi Nirlaba}

Menurut (Morissan 2008), kemunculan Humas pada suatu organisasi ditentukan oleh kebutuhan yang muncul, dimana Humas tersebut memiliki dua fungsi yang dapat dilakukan, yaitu:

1. Fungsi untuk membangun bagian atau departemen di dalam Humas itu sendiri yang menjadi bagian dari manajemen perusahaan.

2. Fungsi untuk menyewa konsultan Humas dalam ranah eksternal untuk melaksanakan fungsi kehumasan di perusahaan bersangkutan.

\section{Hubungan Media}

Hubungan media merupakan salah satu kegiatan perusahaan atau organisasi yang dilakukan oleh Humas. Pada era perkembangan informasi dan teknologi dalam menjalin hubungan baik antara perusahaan dengan media massa bukanlah hal yang mudah untuk dilakukan (Wardhani 2008). Hubungan media juga salah satu perangkat pendukung atau alat Humas dalam menjalankan kegiatan organisasi. Berkenaan dengan hubungan publik dan hubungan pers, Jefkins (1992) menyatakan bahwa kedua hal tersebut merupakan hal penting dalam aktivitas Humas.

\section{Karakteristik Pengguna Media}

Kemudahan memperoleh informasi dalam perkembangan organisasi sangat penting. Informasi yang diterima publik merupakan hasil rancangan media massa. Peran media massa sangat penting dilihat dari sisi publikasi, bahwa media massa mampu menghadirkan fakta aktual yang kemudian akan membentuk opini publik (Wibowo 2010). Segala informasi yang diterima publik tidak hanya berasal dari satu sumber saja. Menurut (Wibowo 2010), informasi dapat tersedia di media massa khususnya media massa online, seperti internet dan media massa cetak, seperti surat kabar dan majalah.

\section{Analisis SWOT}

Analisis SWOT mencakup upaya-upaya untuk mengenali kekuatan, kelemahan, peluang, dan ancaman yang menentukan kinerja perusahaan (Nisak 2013). Menurut Rangkuti (2009) Analisis SWOT didasarkan pada logika yang dapat memaksimalkan kekuatan (strength) dan peluang (opportunities), namun secara bersamaan dapat meminimalkan kelemahan (weaknesses) dan ancaman (threats).

\section{KERANGKA PEMIKIRAN}

Strategi yang terbentuk dapat dilihat dari aktivitas organisasi untuk meningkatkan citranya, yaitu terdiri dari jumlah aktivitas organisasi yang diikuti dan frekuensi publik membaca informasi. Aktivitas organisasi tersebut berasal dari pengembangan konsep efektivitas aktivitas yang dilakukan oleh Humas (Virgiana 2014).

Citra organisasi pada penelitian ini diukur menggunakan konsep citra perusahaan menurut Jefkins (1992) yang dihubungkan dengan karakteristik pengguna media menurut Wibowo (2010). Pandangan yang diberikan publik melalui aktivitas organisasi bisa dilihat pengaruhnya dari karakteristik publik yang terdiri dari usia, jenis kelamin, tingkat pendidikan, jenis pekerjaan dan penggunaan media massa. Hal ini memudahkan organisasi dalam menyusun strategi komunikasi.

Strategi Humas organisasi nirlaba dapat diukur melalui metode Analisis SWOT. Analisis SWOT yang mencakup upaya untuk mengenali kekuatan, kelemahan, peluang dan ancaman berfungsi untuk menentukan kinerja organisasi. Keterkaitan berbagai variabel tersebut secara rinci dapat dilihat pada Gambar 1.

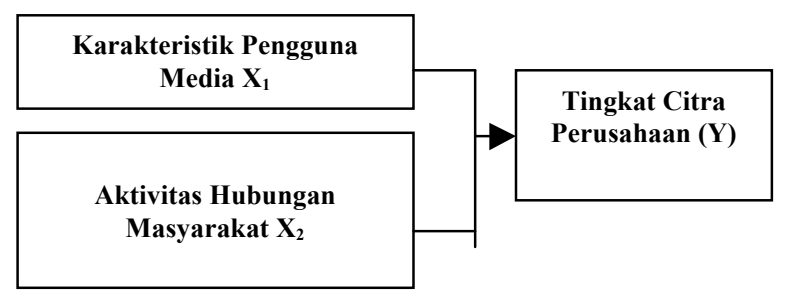

Keterangan:

$\longrightarrow$ : Berhubungan (diuji secara kuantitatif)

Gambar 1 Kerangka pemikiran

\section{Hipotesis Penelitian}

Hipotesis penelitian adalah sebagai berikut:

1. Terdapat hubungan nyata antara (setiap indikator) karakteristik pengguna media dengan (setiap indikator) citra perusahaan.

2. Ada hubungan nyata antara aktivitas Humas (setiap indikator) dengan (setiap indikator) citra perusahaan. 


\section{METODE PENELITIAN}

Penelitian ini menggunakan metode penelitian survai kepada responden. Pendekatan yang digunakan pada penelitian ini adalah pendekatan kuantitatif dan pendekatan kualitatif. Hasil seluruh jawaban yang diperoleh di lapang menggunakan kuesioner dan panduan wawancara dicatat, diolah, dan dianalisis. Informasi yang didapat di lapang kemudian dilengkapi dengan Analisis SWOT (Strength Weakness Opportunities and Threats).

Penelitian ini dilakukan di World Wide Fund for Nature atau WWF-Indonesia yang berada di Graha Simatupang, Jalan Letjen T.B. Simatupang Kav. 38 , Jakarta 12540 dan Institut Pertanian Bogor (IPB) di Jalan Dramaga, Kabupaten Bogor. Waktu yang dibutuhkan pada penelitian ini yakni empat bulan, terhitung dari bulan Februari 2015 sampai dengan Mei 2015.

Lokasi penelitian ditentukan secara sengaja dengan pertimbangan bahwa WWF-Indonesia memiliki aktivitas Humas dan kegiatan pelestarian lingkungan hidup serta sering melakukan hubungan kerjasama dengan organisasi kemahasiswaan di IPB. Kegiatan pelestarian yang dilakukan berupa upaya konservasi yang dibagi menjadi tiga bagian, yaitu Program Kehutanan-Spesies, Program Kelautan-Spesies dan Konservasi Iklim-Energi.

Populasi pada penelitian ini dikumpulkan menggunakan teknik pemilihan responden dengan cara sensus. Populasi pada penelitian ini adalah mahasiswa dan alumni yang tergabung pada dua organisasi kemahasiswaan Institut Pertanian Bogor (IPB) yang pernah bekerjasama dengan WWFIndonesia serta memeriahkan kampanye konservasi sebagai volunteer dalam kurun waktu dua tahun terakhir. Kedua organisasi kemahasiswaan tersebut, yaitu anggota pengurus Fisheries Diving Club (FDC) yang beranggotakan 24 orang dan anggota pengurus Himpunan Mahasiswa Peminat Ilmu-Ilmu Komunikasi dan Pengembangan Masyarakat (HIMASIERA) sebanyak 16 orang. Total mahasiswa yang tergabung pada kedua organisasi tersebut sebanyak 40 orang yang merupakan responden penelitian ini dan informan adalah staff Humas WWF-Indonesia bagian Media Relations dan Digital Channel.

Jenis data yang digunakan dalam penelitian ini adalah data primer dan data sekunder. Data primer merupakan data yang diperoleh melalui wawancara terstruktur menggunakan kuesioner kepada 40 responden, yaitu mahasiswa yang tergabung pada dua organisasi kemahasiswaan IPB yang pernah bekerjasama dan pernah memeriahkan kampanye konservasi sebagai volunteer, serta informan bagian Humas untuk mengidentifikasi bersama peluang, ancaman, kekuatan, dan kelemahan WWFIndonesia. Data sekunder yang digunakan dalam penilitian ini diperoleh dari dokumen organisasi (profil, aktivitas Humas dll), hasil penelitian terdahulu yang sejenis, dan berbagai literatur yang relevan dengan penelitian ini, seperti buku, jurnal ilmiah, skripsi, dan internet. Data primer dan sekunder yang telah diperoleh selanjutnya dilakukan pengolahan data. Data kuantitatif diolah dengan menggunakan Microsoft Excel 2010 dan SPSS for Windows versi 16.

Data kualitatif yang didapatkan saat wawancara menjadi informasi tambahan dan diintegrasikan dengan jawaban yang ada pada kuesioner untuk mendukung dan memperkuat data kuantitatif yang diperoleh. Setelah strategi Humas dalam meningkatkan citra organisasi berhasil dianalisis, langkah selanjutnya adalah penggunaan Analisis SWOT untuk merumuskan strategi Humas yang efektif, agar mengetahui kekuatan, kelemahan, peluang dan ancaman yang dihadapi organisasi (Nisak 2013).

\section{KARAKTERISTIK RESPONDEN BERDASARKAN TINGKAT CITRA ORGANISASI NIRLABA}

\section{Usia}

Usia adalah lama hidup responden pada saat penelitian dilakukan yang dihitung sejak hari kelahiran terhitung dalam satuan tahun. Pada penelitian ini usia dinilai melalui skala ordinal dan masa usia dewasa muda dikelompokkan kembali menjadi tiga kategori, yaitu: usia 19 Tahun; usia dewasa muda awal (skor 1) usia 20-21 Tahun, usia dewasa muda tengah (skor 2), dan usia 22 Tahun: usia dewasa muda tua (skor 3). Berdasarkan hasil penelitian, dari 40 orang responden diketahui bahwa usia termuda ialah 19 tahun dan usia tertua ialah 22 tahun dengan rata-rata usia responden berada di usia 21 tahun.

\section{Jenis kelamin}

Jenis kelamin merupakan sifat fisik dari responden yang tercatat dalam kartu identitas penduduk yang diakui di Indonesia, yaitu laki-laki atau perempuan. Berdasarkan hasil yang diperoleh dari 40 orang 
responden, terdapat 21 orang atau 52.5 persen responden berjenis kelamin laki-laki dan sebanyak 19 orang atau 47.5 persen responden perempuan.

\section{Jenis pekerjaan}

Jenis pekerjaan adalah kegiatan utama yang dilakukan responden dalam kesehariannya untuk memperoleh pendapatan. Pada penelitian hanya ditemukan dua jenis pekerjaan, yaitu swasta dan pekerjaan lainnya (mahasiswa). Berdasarkan hasil penelitian, terlihat bahwa sebagian besar responden masih berstatus sebagai mahasiswa dengan jumlah responden sebanyak 35 orang atau 87.5 persen. Sebanyak 10 orang responden lainnya sebanyak 12.5 persen sudah memiliki gelar sarjana dan saat ini sudah berstatus sebagai pegawai swasta. Menurut pernyataan FNU (24 tahun), sebagai staff Humas untuk Program Kelautan-Spesies, bahwa sebagian besar masyarakat yang bekerjasama dalam aksi kampanye di Bundaran Hotel Indonesia masih berstatus mahasiswa.

\section{Penggunaan media massa}

Penggunaan media massa adalah jenis serta jumlah media massa yang dimiliki oleh responden yang aktif mengikuti publikasi organisasi. Jenis media massa ini terbagi menjadi empat, yaitu radio, televisi, dan surat kabar dengan dikategorikan menjadi, 1) tinggi (skor 3), menggunakan tiga macam media massa; 2) sedang (skor 2), menggunakan dua macam media massa dan 3) rendah (skor 1), menggunakan satu macam media massa.

\section{STRATEGI KOMUNIKASI DAN AKTIVITAS PENYAMPAIAN INFORMASI WWF-INDONESIA DALAM MENINGKATKAN CITRA ORGANISASI NIRLABA}

\section{Strategi komunikasi hubungan masyarakat WWF-Indonesia}

Strategi merupakan alat untuk mencapai tujuan dengan mengatasi ancaman eksternal dan merebut peluang yang ada (Rangkuti 2009). WWF-Indonesia menyadari bahwa dalam melakukan komunikasi dengan publik bukan hanya untuk meningkatkan citra baik organisasi, tetapi juga komunikasi yang memberikan banyak manfaat dan kemudahan bagi publik untuk mendapatkan informasi tentang upaya koservasi yang akan dilakukan.
Ruslan (2001) menjelaskan berbagai macam aspek pendekatan atau strategi Humas suatu organisasi untuk menciptakan iklim organisasi yang kondusif. Terdapat beberapa aspek yang ditemukan dalam strategi komunikasi yang dilakukan Humas WWFIndonesia, diantaranya:

1. Strategi Operasional

Humas WWF-Indonesia mampu mendengarkan apa yang disampaikan masyarakat mengenai masalah yang dihadapi. Hal ini dapat dilihat dari salah satu upaya konservasi yang dilakukan melalui kampanye Nasib Gajah. Salah satu cara yang paling signifikan adalah mengajak masyarakat lokal mengerti cara menghadapi gajah yang masuk ke dalam kawasan pemukiman.

2. Pendekatan Persuasif dan Edukatif

Pendekatan persuasif dan edukatif dilakukan terkait fungsi Humas untuk menciptakan komunikasi dua arah dengan menyebarkan informasi organisasi. Humas WWFIndonesia melalui Divisi Media Relations dan Digital Channel melakukan komunikasi dua arah dengan publiknya. Selain itu, WWF-Indonesia juga melakukan upaya konservasi melalui aksi kampanye yang dilakukan di beberapa kota besar di Indonesia, seperti kampanye Nasib Gajah di Bundaran Hotel Indonesia pada tanggal 9 November 2014.

3. Pendekatan Tanggung Jawab Sosial Humas Pendekatan tanggung jawab sosial bisa dilihat dari hubungan kerjasama WWF Program Riau yang bekerjasama dengan BKSDA Riau untuk mengurangi konflik manusia dan gajah melalui teknik Flying Squad. Hal ini dinilai efektif karena dapat menimbulkan kesadaran masyarakat sekitar daerah konservasi untuk lebih peduli pada lingkungan sekitar, yaitu isu konflik manusia dan gajah.

4. Pendekatan Kerjasama

Humas berupaya membina hubungan yang harmonis antara organisasi dengan stakeholders untuk meningkatkan kerjasama. Salah satu bentuk kerjasama yang dijalin WWF-Indonesia dengan pemerintah adalah kerjasama dengan Kementerian Kelautan dan Perikanan (KKP) terkait upaya ketahanan pangan. Kesepakatan yang terjalin di kedua belah pihak dimaksudkan untuk memperkuat 
upaya pemerintah dalam memenuhi kebijakan terkait ketahanan, kedaulatan, dan keberlanjutan pangan terhadap produkproduk perikanan, khususnya di wilayah Segitiga Terumbu Karang. Kesepakatan ini mencerminkan kerja sama tahap II antara WWF-Indonesia dan KKP dengan berakhirnya Kesepakatan Bersama periode 2010-2014.

5. Pendekatan Koordinatif dan Integratif

Pendekatan koordinatif dan integratif dijelaskan dengan fungsi Humas yang hanya mewakili suatu organisasi, tetapi peranan lebih luas berpartisipasi dalam menunjang program pembangunan nasional dan mewujudkan ketahanan nasional di bidang politik, ekonomi, sosial budaya (Poleksosbud), dan Hankamnas. Hal ini juga dapat dilihat dari kesepakatan antara WWFIndonesia dengan KKP sebagai cerminan kerjasama tahap II antara keduanya.

\section{Aktivitas Penyampaian Informasi WWF- Indonesia}

\section{a. Pemberitaan di media massa cetak}

Bentuk aktivitas penyampaian informasi yang dilakukan oleh Humas WWF-Indonesia bertujuan untuk memberikan berita yang sebenar-benarnya kepada publik, sehingga terbentuk kesan yang baik terhadap apa yang sudah dilakukan organisasi. Salah satunya adalah melakukan hubungan baik dengan media melalui divisi Media Relations yang bersentuhan langsung dengan media massa nasional atau lokal. Telah banyak pemberitaan mengenai kegiatan organisasi termasuk upaya konservasi yang didistribusikan kepada beberapa media massa cetak nasional, seperti koran Kompas dan Majalah Panorama.

\section{b. Pemberitaan di media massa elektronik}

WWF-Indonesia merupakan salah satu organisasi nirlaba yang fokus pada upaya konservasi di Indonesia. Perkembangan teknologi dan informasi yang begitu pesat saat ini menjadi peluang bagi Humas WWF-Indonesia sebagai jembatan dengan publik dalam melakukan publikasi. Pemberitaan di media massa elektronik juga dilakukan melalui website resmi milik WWF-Indonesia, yakni http://www.wwf.or.id/. Selain itu, WWF-Indonesia juga memanfaatkan bermacam media sosial untuk menarik simpatik publik menganai isu-isu yang dipublikasikan, seperti fanpage Facebook WWF Indonesia dan Twitter account yang sudah terferivikasi,yakni@WWF_ID.

\section{AKTIVITAS HUBUNGAN MASYARAKAT WWF-INDONESIA DAN TINGKAT CITRA DALAM MENYAMPAIKAN INFORMASI}

\section{Tingkat pengetahuan ragam aktivitas dan frekuensi aktivitas hubungan masyarakat WWF-Indonesia}

Berdasarkan data yang sudah diolah, didapatkan hasil bahwa publikasi mengenai kegiatan organisasi serta upaya konservasi yang diberikan lebih banyak diketahui oleh responden melalui media massa elektronik, yaitu sebesar 22 persen. Pada publikasi melalui media massa cetak, yakni surat kabar/koran memiliki porsi yang paling kecil, yaitu 9 persen.

Publikasi melalui media massa cetak ataupun elektronik sudah tersegmentasi dengan tepat, namun responden lebih memilih media massa elektronik karena kemudahan akses yang dimilikinya. Berdasar hasil olahan data diketahui bahwa sebesar 47.5 persen responden memiliki tingkat pengetahuan menganai ragam aktivitas penyampaian pesan yang tinggi. Pada tingkat pengetahuan responden dari kategori rendah, yaitu sebesar 15 persen. Sejalan dengan ragam media untuk penyampaian pesan organisasi, pengetahuan responden mengenai frekuensi penyampaian informasi melalui jenis media tersebut juga berada pada kategori tinggi, yaitu sebesar 87.5 persen.

\section{Tingkat tingkah laku publik dan tingkat citra WWF-Indonesia}

Secara keseluruhan, penilain responden terhadap tingkat tingkah laku tentang WWF-Indonesia berada pada kategori tinggi dengan presentase sebesar 65 persen. Sebanyak 72.5 persen responden mempercayai informasi yang diberikan organisasi melalui beragam media massa yang digunakan. Selain itu, kesan responden terhadap kepuasan informasi yang diberikan organisasi tergolong tinggi, yaitu sebanyak 67.5 persen. Sebanyak 95 persen mengungkapkan bahwa informasi yang diberikan organisasi sangat menarik. Selain informasi yang beragam, gambar yang dibagikan menjadi nilai tambah dari pemberitaan WWFIndonesia. Kesan yang diberikan publik terhadap organisasi melalui informasi yang diterima adalah tinggi sebesar 77.5 persen. 


\section{ANALISIS HUBUNGAN KARAKTERISTIK INDIVIDU PENGGUNA MEDIA MASSA DENGAN CITRA PERUSAHAAN WWF- INDONESIA}

\section{Hubungan usia individu pengguna media massa dengan tingkat tingkah laku publik}

Hasil pengolahan data menunjukan jumlah responden terbanyak terdapat pada kategori usia dewasa muda tengah dengan presentase sebesar 67.9 untuk tingkah laku publik tinggi. Nilai signifikasi yang dihasilkan dari uji korelasi keduanya sebesar 0.168 . Hasil uji korelasi antara usia individu pengguna media massa dengan tingkah laku publik menunjukkan bahwa nilai koefisien korelasi sebesar 0.222 . Sehingga, dapat disimpulkan bahwa keduanya memiliki koefisien korelasi yang sangat lemah dan tidak signifikan.

\section{Hubungan usia individu pengguna media massa dengan tingkat citra perusahaan}

Hasil pengolahan data menunjukan jumlah responden terbanyak terdapat pada kategori usia dewasa muda tengah dengan presentase sebesar 71.4 untuk tingkat citra tinggi. Nilai signifikasi yang dihasilkan dari uji korelasi keduanya sebesar 0.153. Hasil uji korelasi antara usia individu pengguna media massa dengan tingkat citra perusahaan menunjukan nilai koefisien korelasi sebesar 0.230. Maka, disimpulkan bahwa keduanya memiliki koefisien korelasi yang sangat lemah dan tidak signifikan.

Hubungan jenis kelamin individu pengguna media massa dengan tingkat tingkah laku publik

Hasil pengolahan data menunjukan bahwa presentase tertinggi sebesar 62.0 persen pada kategori jenis kelamin laki-laki. Selain itu, hasil uji Chi Square antara jenis kelamin responden dengan tingkat citra perusahaan menunjukan bahwa nilai signifikasi sebesar 0.613 . Artinya, kedua variable tersebut tidak signifikan.

Hubungan jenis kelamin individu pengguna media massa dengan tingkat citra perusahaan

Hasil pengolahan data menunjukan bahwa presentase tertinggi sebesar 76.2 persen pada kategori jenis kelamin laki-laki. Selain itu, hasil uji Chi Square antara jenis kelamin responden dengan tingkat citra perusahaan menunjukan bahwa nilai signifikasi sebesar 0.567 . Artinya, kedua variable tersebut tidak signifikan.

Hubungan tingkat pendidikan terakhir individu pengguna media massa dengan tingkat tingkah laku publik

Hasil pengolahan data menunjukkan jumlah responden terbanyak terdapat pada kategori tingkat pendidikan sedang atau mahasiswa semester 6 dan 8 , yaitu sebesar 65.5 persen dengan tingkah laku publik tinggi. Nilai signifikasi yang dihasilkan dari uji korelasi keduanya sebesar 0.401. Hasil uji korelasi antara pendidikan terakhir individu pengguna media massa dengan tingkah laku publik menunjukan bahwa nilai koefisien korelasi sebesar 0.137. Sehingga, dapat disimpulkan keduanya memiliki koefisien korelasi sangat lemah dan tidak signifikan.

Hubungan tingkat pendidikan terakhir individu pengguna media massa dengan tingkat citra perusahaan

Hasil pengolahan data menunjukan jumlah responden terbanyak terdapat pada kategori tingkat pendidikan sedang atau mahasiswa semester 6 dan 8, yaitu sebesar 72.5 pesen dengan tingkat citra tinggi. Nilai signifikasi yang dihasilkan dari uji korelasi keduanya sebesar 0.946 . Hasil uji korelasi antara pendidikan terakhir individu pengguna media massa dengan tingkat citra perusahaan menunjukan bahwa nilai koefisien korelasi sebesar 0.011 . Sehingga, dapat disimpulkan bahwa keduanya memiliki koefisien korelasi sangat lemah, dan tidak signifikan.

Hubungan jenis pekerjaan individu pengguna media massa dengan tingkat tingkah laku publik

Hasil pengolahan data menunjukan bahwa jumlah responden terbanyak terdapat pada kategori lainnya atau mahasiswa sebesar 62.9 persen dengan tingkah laku publik tinggi. Selain itu, hasil uji Chi Square antara jenis kelamin responden dengan tingkat citra perusahaan menunjukan bahwa nilai signifikasi sebesar 0.735. Artinya, kedua variable tidak signifikan.

Hubungan jenis pekerjaan individu pengguna media massa dengan tingkat citra perusahaan

Hasil pengolahan data menunjukkan bahwa jumlah responden terbanyak terdapat pada kategori jenis pekerjaan lainnya atau mahasiswa, yaitu sebesar 
77.2 persen dengan tingkat citra tinggi. Selain itu, hasil uji Chi Square antara jenis kelamin responden dengan tingkat citra perusahaan menunjukan bahwa nilai signifikasi sebesar 0.659. Artinya, kedua variable tersebut tidak signifikan.

Hubungan jenis penggunaan media individu pengguna media massa dengan tingkat tingkah laku publik

Hasil pengolahan data menunjukan jumlah responden terbanyak terdapat pada kategori pengguna media massa tinggi, yaitu sebesar 77.4 persen dengan tingkat tingkah laku publik tinggi. Nilai signifikasi yang dihasilkan dari uji korelasi keduanya sebesar 0.007 . Hasil uji korelasi antara jenis penggunaan media individu dengan tingkah laku publik menunjukan bahwa nilai koefisien korelasi sebesar 0.419. Artinya, keduanya memiliki koefisien korelasi yang cukup dan signifikan.

Hubungan jenis penggunaan media individu pengguna media massa dengan tingkat citra perusahaan

Hasil pengolahan data menunjukan jumlah responden terbanyak terdapat pada kategori pengguna media massa tinggi, yaitu sebesar 96.7 persen dengan tingkat citra tinggi. Nilai signifikasi yang dihasilkan dari uji korelasi keduanya sebesar 0.000 . Hasil uji korelasi antara jenis penggunaan media individu pengguna media massa dengan tingkat citra perusahaan menunjukan bahwa nilai koefisien korelasi sebesar 0.850 . Sehingga, dapat disimpulkan bahwa keduanya memiliki koefisien korelasi yang sangat kuat dan signifikan dengan tingkat citra perusahaan.

\section{ANALISIS HUBUNGAN AKTIVITAS HUBUNGAN MASYARAKAT DENGAN CITRA PERUSAHAAN WWF-INDONESIA}

\section{Hubungan ragam aktivitas dengan tingkat tingkah laku publik}

Hasil pengolahan data menunjukan jumlah responden terbanyak terdapat pada kategori ragam aktivitas tinggi, yaitu sebesar 84.2 persen dengan tingkat tingkah laku publik tinggi. Nilai signifikasi yang dihasilkan dari uji korelasi keduanya sebesar 0.018. Hasil uji korelasi antara ragam aktivitas dengan tingkah laku publik menunjukan bahwa nilai koefisien korelasi sebesar 0.373. Sehingga, dapat disimpulkan bahwa keduanya memiliki koefisien korelasi yang cukup dan signifikan.

\section{Hubungan ragam aktivitas dengan tingkat citra perusahaan}

Hasil pengolahan data menunjukan jumlah responden terbanyak terdapat pada kategori ragam aktivitas tinggi, yaitu sebesar 84.2 persen dengan tingkat citra tinggi. Selain itu, nilai signifikasi yang dihasilkan dari uji korelasi keduanya sebesar 0.261. Hasil uji korelasi antara ragam aktivitas dengan tingkat citra perusahaan Sehingga, dapat disimpulkan bahwa keduanya memiliki koefisien korelasi yang sangat lemah dan tidak signifikan.

\section{Hubungan frekuensi aktivitas dengan tingkat tingkah laku publik}

Hasil pengolahan data menunjukan jumlah responden terbanyak terdapat pada kategori frekuensi aktivitas tinggi, yaitu sebesar 75.7 persen dengan tingkah laku publik tinggi. Selain itu, nilai signifikasi yang dihasilkan dari uji korelasi keduanya sebesar 0.000 . Hasil uji korelasi antara frekuensi aktivitas dengan tingkah laku publik menunjukan bahwa nilai koefisien korelasi sebesar 0.527. Sehingga, dapat disimpulkan bahwa keduanya memiliki memiliki koefisien korelasi yang cukup dan signifikan.

\section{Hubungan frekuensi aktivitas dengan tingkat citra perusahaan}

Hasil pengolahan data menunjukan jumlah responden terbanyak pada kategori frekuensi aktivitas tinggi, yaitu sebesar 84.85 persen dengan tingkat citra tinggi. Selain itu, nilai signifikasi yang dihasilkan dari uji korelasi keduanya sebesar 0.019. Hasil uji korelasi antara frekuensi aktivitas dengan tingkat citra menunjukkan bahwa nilai koefisien korelasi sebesar 0.368. Sehingga, dapat disimpulkan bahwa keduanya memiliki koefisien korelasi yang cukup dan signifikan.

\section{ANALISIS SWOT}

\section{Analisis Faktor Internal}

a. Analisis kekuatan (Strength)

Terdapat 5 (lima) kekuatan yang dimiliki oleh WWF-Indonesia dalam mengelola informasi, yakni sebagai berikut:

1. Media Relations, merupakan aktivitas utama yang menjadi kekuatan bagi organisasi dalam menciptakan serta meningkatkan citra.

2. Pengenalan konservasi pada publik telah disesuaikan pada Misi WWF-Indonesia untuk 
melestarikan, merestorasi serta mengelola ekosistem dan keanekaragaman hayati di Indonesia.

3. Aktivitas Internal communication, dilakukan untuk tetap menjaga hubungan yang baik diantara pekerja dan pimpinan organisasi.

4. Budaya organisasi yang kuat dapat dilihat dari aktivitas dan interaksi yang dibangun oleh para pekerja selama di kantor.

5. Time Event, hal lain yang menjadi aktivitas internal communication, ialah adanya kalender event /time event yang dijadwalkan ketat oleh Media Relations officer.

b. Analisis kelemahan (Weaknesses)

Terdapat dua kelemahan bagi WWF-Indonesia dala mengelola informasi sebagai berikut:

1. Kelemahan yang dirasakan organisasi, yaitu otoritas yang kurang ketika sedang di lapang dalam pengambilan data.

2. Berita negatif dari media massa mengenai organisasi juga menjadi kelemahan organisasi dalam membentuk serta meningkatkan citra di mata publik.

\section{Analisis Faktor Eksternal}

a. Analisis ancaman (Threats)

Bagi WWF-Indonesia keberdaannya sebagai LSM asing dan hubungan harmonis dengan swasta menjadi ancaman tersendiri, yang dijelaskan sebagai berikut:

1. Pandangan publik tentang status WWFIndonesia sebagai LSM asing merupakan suatu kecaman tersendiri untuk organisasi.

2. Hubungan yang kurang harmonis dengan salah satu perusahaan swasta karena permasalahan lingkungan yang diciptakan perusahaan tersebut menjadi salah satu ancaman WWF-Indonesia.

\section{b. Analisis peluang (Opportunities)}

Namun dibalik ancaman tersebut, WWF-Indonesia memiliki peluang sebagai berikut:

1. Analisis media monitoring yang dilakukan WWF-Indonesia melalui jasa provider media monitoring memudahkan organisasi untuk mendata media yang mempublikasikan informasi seputar WWF-Indonesia.

2. Beberapa kelebihan yang dimiliki kompetitor yang memiliki tujuan yang sama dalam pelestarian lingkungan menjadi salah satu peluang yang dirasakan WWF-Indonesia.

3. Perkembangan teknologi dan informasi yang semakin pesat saat ini memudahkan organisasi melakukan publikasi kegiatan dan upaya konservasi yang dilakukannya.

Merujuk pada hasil analisa faktor internal dan faktor eksternal maka penghitungan skor strategi internal dan eksternal tersaji pada Tabel 1 dan Tabel 2.

Tabel 1 Faktor strategi internal (IFAS) WWFIndonesia

\begin{tabular}{lccc}
\hline \multicolumn{1}{c}{$\begin{array}{c}\text { Indikator Faktor } \\
\text { Internal }\end{array}$} & Bobot & Rating & Skor \\
\hline Kekuatan & & & \\
\hline $\begin{array}{l}\text { Media Relations } \\
\text { Pengenalan konservasi } \\
\text { pada publik }\end{array}$ & 0.2 & 4 & 0.8 \\
$\begin{array}{l}\text { Internal commu- } \\
\text { nication, outing team }\end{array}$ & 0.1 & 4 & 0.4 \\
$\begin{array}{l}\text { Budaya organisasi } \\
\text { yang kuat }\end{array}$ & 0.1 & 3 & 0.3 \\
$\begin{array}{l}\text { Time event } \\
\text { Kelemahan }\end{array}$ & 0.19 & 3 & 0.57 \\
\hline $\begin{array}{l}\text { Peran terbatas dalam } \\
\text { penganan konservasi } \\
\text { di lapang jika belum } \\
\text { ada pihak pemerintah }\end{array}$ & 0.01 & 4 & 0.4 \\
$\begin{array}{l}\text { yang hadir } \\
\text { Pemberitaan negatif di } \\
\text { media massa mengenai } \\
\text { kegiatan WWF- }\end{array}$ & & & \\
$\begin{array}{l}\text { Indonesia } \\
\text { Total }\end{array}$ & & & \\
\hline & & & \\
\hline
\end{tabular}

Tabel 2 Faktor strategi eksternal (EFAS) WWFIndonesia

\begin{tabular}{lrrr}
\hline \multicolumn{1}{c}{$\begin{array}{c}\text { Indikator Faktor } \\
\text { Eksternal }\end{array}$} & Bobot & Rating & Skor \\
\hline Peluang & & & \\
\hline $\begin{array}{l}\text { Analisis media } \\
\text { monitoring }\end{array}$ & 0.3 & 4 & 1.2 \\
$\begin{array}{l}\text { Memantau aktivitas } \\
\text { kompetitor }\end{array}$ & 0.2 & 2 & 0.4 \\
$\begin{array}{l}\text { Perkembangan teknologi } \\
\text { dan informasi }\end{array}$ & 0.25 & 4 & 1 \\
\hline Kelemahan & & & \\
\hline $\begin{array}{l}\text { Pandangan publik } \\
\text { mengenai status WWF } \\
\text { sebagai LSM asing }\end{array}$ & 0.15 & 3 & 0.45 \\
$\begin{array}{l}\text { Hubungan yang kurang } \\
\text { harmonis dengan salah } \\
\text { satu perusahaan swasta }\end{array}$ & 0.1 & 4 & 0.4 \\
\hline Total & 1.00 & & 3.05 \\
\hline
\end{tabular}




\section{Susunan Formulasi Strategi}

Merujuk pada hasil penghitungan bobot, rating dan skor pada masing-masing strategi, maka formulasi strategi yang dapat digunakan oleh WWF-Indonesia tersaji pada Gambar 2.

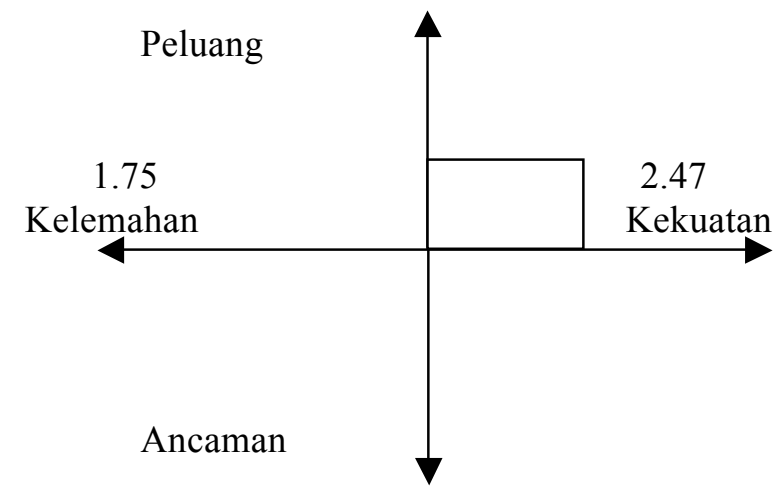

Gambar 2 Posisi kuadran SWOT WWFIndonesia

\section{Pemilihan Alternatif Strategi dengan Matriks SWOT}

a. Strategi Hubungan Masyarakat Strength Opportunities (S-O)

1. Memperluas hubungan baik dengan media massa lokal maupun nasional.

2. Memperluas hubungan kerjasama dengan masyarakat lokal yang mengalami konflik dengan hewan di sekitarnya. Hal ini perlu ditingkatkan agar upaya konservasi yang dilakukan organisasi dapat berjalan lancar.

b. Strategi Hubungan Masyarakat Weaknesses Opportunities (W-O)

1. Meningkatkan jumlah publikasi di media massa cetak maupun elektronik mejadi salah satu strategi yang menjadi penting untuk organisasi. Hal ini dikarenakan paparan media massa mengenai organisasi secara konsisten dengan frekuensi yang tinggi akan memberikan pengaruh pada pandangan publik terhadap organisasi.

2. Melakukan hubungan kerjasama dengan kompetitor dalam pelestarian lingkungan dapat menguntungkan kedua belah pihak. Selain menunjukkan hubungan baik kepada publik, masing-masing LSM dapat mempergunakan setiap kekuatan yang dimilikinya guna keberhasilan pelestarian lingkungan di Indonesia.
3 Memperluas hubungan kerjasama dengan pemerintah pusat maupun daerah dalam upaya konservasi yang dilakukan organisasi. Keberhasilan yang dicapai dari upaya konservasi merupakan campur tangan pemerintah pusat dan daerah.

c. Strategi Hubungan Masyarakat Strength Threats (S-T)

1. Menfaatkan hubungan yang baik dengan media massa lokal maupun nasional dengan cara memberikan informasi yang sebenarbenarnya. Transparasi antar pihak menjadi suatu hal yang paling penting ketika organisasi dan media massa melakukan hubungan kerjasama.

2. Menjalin hubungan yang baik dengan perusahaan swasta melalui kerjasama dalam pelestarian lingkungan Indonesia.

d. Strategi Hubungan Masyarakat Weaknesses Threats (W-T)

1. Peningkatan upaya konservasi di setiap daerah di Indonesia melalui hubungan yang baik dengan pemerintah pusat maupun daerah. Peran WWF-Indonesia sebagai yayasan atau Lembaga Swadaya Masyarakat yang bergerak pada isu lingkungan sangat dibutuhkan oleh pemerintah dalam pelestarian lingkungan.

\section{SIMPULAN DAN SARAN}

\section{Simpulan}

Penjabaran upaya strategi yang dilakukan WWFIndonesia terangkum dalam lima aspek pendekatan Humas menurut Ruslan (2001) dapat ditemukan pada perencanaan komunikasi WWF-Indonesia.

Aktivitas penyampaian informasi oleh Humas WWF-Indonesia dilakukan melalui pemberitaan di media massa cetak dan media massa elektronik. Publikasi kegiatan dan upaya konservasi di media massa cetak majalah dan elektronik masuk dalam kategori tinggi, yaitu sebesar 22 persen untuk media elektronik dan 15 persen untuk media massa cetak majalah. Hal tersebut didukung dengan pengetahuan ragam aktivitas dan frekuensi aktivitas yang juga tinggi, yaitu sebesar 47.5 persen responden memiliki tingkat pengetahuan yang tinggi untuk ragam aktivitas dan 87.5 persen untuk tingkat pengetahuan responden dari hasil pengolahan 
frekuensi aktivitas. Artinya, sebagian besar responden sudah mengenal beragam media untuk memperoleh informasi seputar WWF-Indonesia. Komponen tingkat citra yang terbagi menjadi tingkat tingkah publik dan tingkat citra perusahaan WWF-Indonesia masuk dalam kategori tinggi, yaitu sebesar 65 persen untuk tingkat tingkah laku publik dan 77.5 persen untuk tingkat citra.

Terdapat 14 analisis hubungan dari pengolahan data karakteristik individu pengguna media massa serta aktivitas Humas terhadap tingkat citra perusahaan, namun hanya lima analisis hubungan yang menunjukkan perolehan nilai signifikan dari hasil uji korelasi rank spearman dan chi square.

Berdasar hasil olahan data analisis SWOT diketahui WWF-Indonesia dalam melakukan upaya konservasi tidak lepas dari ancaman yang datang dari lingkungan eksternal, tetapi organisasi juga memiliki kekuatan internal dan peluang yang mampu menghadapi berbagai ancaman tersebut.

\section{Saran}

1. Strategi Humas yang dilakukan WWFIndonesia perlu ditingkatkan melalui frekuensi kegiatan yang terus dilakukan bersama dengan berbagai pihak terkait, seperti pemerintah pusat atau daerah, siswa atau mahasiswa serta LSM kompetitor

2. Aktivitas penyampaian informasi yang dilakukan oleh WWF-Indonesia perlu ditingkatkan kembali untuk media massa cetak koran. Hal tersebut dikarenakan responden di kalangan mahasiswa jarang menemukan berita konservasi WWFIndonesia di koran yang mereka baca. Artinya, informasi yang diberikan organisasi untuk media massa cetak seperti koran kurang menarik saat diadakannya media briefing organisasi, sehingga secara tidak langsung citra yang terbentuk di mata publik tidak sesuai dengan apa yang diharapkan. WWF-Indonesia disamping perlu mempertahankan citra yang baik di mata publik juga perlu untuk meningkatkannya.

3. Penelitian selanjutnya dapat dilakukan menggunakan indikator serupa dengan jumlah sample yang lebih banyak dan lebih beragam. Sehingga hasil yang didapatkan lebih bersifat heterogen dan lebih valid.

4. WWF-Indonesia perlu semakin peduli terhadap kekuatan serta kelemahan yang dapat ditemukan dari dalam organisas tanpa melupakan peluang dan ancaman yang datang dari luar organisasi. Selain itu, hubungan baik dengan pemerintah pusat maupun pemerintah daerah guna kelancaran setiap upaya konservasi yang dilakukan d Indonesia. Kerjasama yang sudah terjalin dapat dibentuk semakin baik dengan mengadakan pertemuan antar pihak.

\section{DAFTAR PUSTAKA}

Cutlip, Scott M, Allen H, Center, Broom,

Glen M. 2005. Effective Public Relations. Edisi 8 Jakarta (ID): PT. Indeks Kelompok Gramedia.

Darmastuti. 2012. Media Relations, Konsep, Strategi dan Aplikasi. Jakarta (ID): CV ANDI OFFSET.

Jefkins F. 1992. Public Relations. Jakarta (ID): Intermasa.

[Kemenhut] Kementerian Kehutanan Indonesia. 2012. [Internet]. [Dikutiptanggal 14 Oktober 2014]. Dapat diakses di: http://www.menlh.go.id/status-lingkunganhidup-indonesia-2012/

Khadijah S. 2011. Strategi Public Relations dalam Membangun Citra Perusahaan (Studi Deskriptif Membangun Hubungan Baik Dengan Media Dalam Upaya Meningkatkan Citra Perusahaan). [Internet]. [16 September 2014]. Dapat diakses di: http://webcache.googleusercontent.com/searc h?q=cache:2uZfie9dTf0J:portalgaruda.org/do wnload article.php

[KLH] Status Lingkungan Hidup Indonesia. 2012. [Internet]. [15 Oktober 2014]. Dapat diakses di: $\quad$ http://www.slideshare.net/Oswar Mungkasa/status-lingkungan-hidupindonesia-2012-pilar-lingkungan-hidupindonesia

Monani S. 2014. Aktivitas Public Relations Mal Ciputra Seraya Pekanbaru Dalam

UpayaMeningkatkan Citra Perusahaan. [Internet]. [14 Oktober 2014]. Dapat diakses di: http://jom.unri.ac.id/index.php/ JOMFSIP/article/view/2834

Morissan. 2008. Manajemen Public Relations. Jakarta (ID): Kencana.

Mugniesyah SS. 2006. Pendidikan Orang Dewasa. Departemen Komunikasi dan Pengembagan Masyarakat, Fakultas Ekologi Manusia. Bogor (ID): Institut Pertanian Bogor. 
Novianti N. 2010. Strategi Public Relations Dalam Mempertahankan Eksistensi Corporate Image Melalui Opini Publik (Studi Kasus PT. Indocement Tunggal Prakarsa Tbk.). [Skripsi]. Bogor (ID). Institut Pertanian Bogor.

Nisak Z. Analisis SWOT Untuk Menentukan Strategi Kompetitif. [Internet]. [22 Desember 2014]. Dapat diakses di:http://journal.unisla.ac.id/index.php?p=jou rnal\&id $=122$

Nur E. 2013 Peran Public Relations Terhadap Loyalitas Konsumen Indosat di Kota Makassar. [Internet]. [16 September 2014]. Dapat diakses di: http://webcache.googleusercontent.com/searc $\underline{\mathrm{h} ? \mathrm{q}=\text { cache:1QZ3RwVLFZMJ:jurnal.kominfo. }}$ go.id/

Paskual MF, Ansar M. 2012. Akuntabilitas LSM, Milik Donor atau Publik. [Internet]. [16 September 2014]. Dapat diakses di: http://asp.trunojoyo.ac.id/wpcontent/uploads/2014/03/057-ASPGG-06.pdf

Ruslan R. 2001. Praktik dan Solusi Public Relations dalam Situasi Krisis dan Pemulihan Citra. Jakarta (ID): Ghalia Indonesia.

Rangkuti F. 2009. Analisis SWOT: Teknik membedah kasus bisnis. Jakarta (ID): PT. Gramedia Pustaka Utama.

Singarimbun M, Effendi. 2006. Metode Penelitian Survai. Jakarta (ID): Pustaka LP3ES. 336 hal.

Sutrisno B. 2013. Langkah Strategis Penyelamatan Lingkungan Hidup Sebuah Kajian Teoritis Yuridis Normatif. [Internet]. [15 Oktober 2014]. Dapat diakses di: http://journal. umsida.ac.id/files/Tulisan\%20Bambang.pdf

Sulistyasningtyas ID. 2004. Pemberitaan di Media Massa sebagai Pembentuk Reputasi Organisasi. [Internet]. [29 Desember 2014]. Dapat diakses di: http://ojs.uajy.ac.id/ index.php/jik/article/view/245

Susanti E. 2013. Strategi Public Relations dalam Meningkatkan Citra Organisasi. [Internet].[16 September 2014]. Dapat diakses di: http://ejournal.unesa.ac.id/ index.php/jpap/article/view/9338/0

Utami FN. 2013. Peran Public Relations Pada Organisasi Nirlaba Program Konservasi Kelautan WWF-Indonesia. [Skripsi]. [Internet]. [14 Oktober 2014]. [SKPM IPB]. Dapat diakses di: http://repository.ipb.ac.id/ handle/123456789/69167
[UU] Undang-Undang No. 23 Tahun 1997 tentang Pengelolaan Lingkungan Hidup (UUPLH). Dapat diakses di: https://www.pu.go.id/ uploads/services/2011-11-29-12-32-35.pdf

Virgiana. 2014. Strategi Public Relations dalam Membentuk Opini Publik PT Telekomunikasi Indonesia Tbk.[Skripsi]. Bogor (ID). Institut Pertanian Bogor.

Wardhani D. 2008. Hubungan Media: Sarana Membangun Reputasi Organisasi. Jakarta (ID): Graha Ilmu.

Waskito B. 2014. Peningkatan Citra Organisasi dalam Membangun Keunggulan Kompetitif (Competitive Advantage) di Perguruan Tinggi Swasta. [Internet]. [14 Oktober 2014]. Dapat diakses di: http://jurnal.ubl. ac.id/index.php/JIK/article/view/455

Wibowo I. 2010. Pengaruh Penggunaan Media Massa, Komunikasi Interpersonal, dan Dukungan Sosial Terhadap Motivasi Harapan Hidup Pada Penderita Kanker. [Thesis]. Semarang (ID). Universitas Diponegoro.

[WWF-Indonesia] World Wide Fund for Nature. 2015. Kegiatan Konservasi WWF Indonesia. [Internet]. [Dikutip tanggal 14 Januari 2015]. Dapat diakses di http://www.wwf.or.id/tentang_wwf/ 
Adiningtyas, Hubeis \& Hapsari / JSKPM 1(2): 223-236 